Praca poglądowa/Review paper

\title{
Porównanie objętości narządów krytycznych z obszaru mózgowia wyznaczonych manualnie i automatycznie dla trzech systemów planowania leczenia
}

\section{Comparison of the volumes of organs at risk for the brain tumors determined manually and automatically for the three treatment planning systems}

\author{
Sara Styśs ${ }^{1}$, Magdalena Charmacińska ${ }^{1}$, Agnieszka Skrobała $^{1,2}$ \\ ${ }^{1}$ Zakład Fizyki Medycznej, Wielkopolskie Centrum Onkologii, Poznań \\ ${ }^{2}$ Katedra i Zakład Elektroradiologii, Uniwersytet Medyczny, Poznań
}

\section{Streszczenie}

W Polsce nowotwory mózgowia stanowią 2\% wszystkich nowotworów złośliwych, a istotną rolę w ich leczeniu odgrywa radioterapia. Obszar mózgowia jest szczególnie istotny ze względu na bliskość sąsiadujących znaczących dla życia narządów. W procesie przygotowania leczenia jednym z najistotniejszych kroków jest wyznaczenie konturów narządów krytycznych. W pracy zbadano różnice pomiędzy objętościami narządów krytycznych wyznaczonych manualniew systemieplanowanialeczenia Eclipse(Varian) orazzwykorzystaniem zaimplementowanych narzędzi do automatycznego wyznaczania struktur w systemach planowania leczenia iPlan (BrainLab) oraz MultiPlan (Accuray). Wykazano, iż objętości struktur wyznaczanych manualnie są większe od tych wyznaczanych automatycznie, jednak różnice te nie wpływają znacząco na proces leczenia i bezpieczeństwo pacjentów.
Abstract
Adres do korespondencji
Agnieszka Skrobała
Zakład Fizyki Medycznej,
Wielkopolskie Centrum Onkologii, ul. Garbary 15, 61-866 Poznań, Polska
Telefon. +48618850553
e-mail: agnieszka.skrobala@wco.pl

In Poland, brain tumors account for $2 \%$ of all malignant tumors, and radiotherapy plays an important role in their treatment. The area of the brain is unique due to the proximity of adjacent important organs. One of the most important steps in the treatment preparation process is contouring the organs at risk. The 
study examined the differences between the volumes of critical organs determined manually in the Eclipse (Varian) treatment planning system and the implemented tools for automatic determination of structures in the iPlan (BrainLab) and MultiPlan (Accuray) treatment planning systems. It has been shown that the volumes of structures determined manually are greater than those determined automatically; however, these differences do not significantly affect the treatment process and patient safety.

Słowa kluczowe: radioterapia, guzy mózgu, autokonturowanie, narządy krytyczne, planowanie leczenia

Keywords: radiotherapy, brain tumors, auto-contouring, organs at risk, treatment planning

\section{Wprowadzenie}

W Polsce nowotwory mózgowia stanowią 2\% zachorowań na wszystkie nowotwory złośliwe. Ryzyko zachorowania wzrasta z wiekiem, przy czym są to jedne z najczęstszych nowotworów wieku dziecięcego. Stanowią ponad 15\% zachorowań u pacjentów onkologicznych poniżej 19 roku życia. Najliczniejszą grupę stanowią guzy przerzutowe w obszarze mózgowia. Podstawową metodą leczenia nowotworów mózgowia jest zabieg chirurgiczny, rzadko stosuje się chemioterapię, ale duże znaczenie w leczeniu nowotworów centralnego układu nerwowego ma radioterapia $[1,2]$.

Najczęstszymi guzami pierwotnymi mózgu są tzw. nowotwory gleju astrocytarnego, czyli gwiaździstego, stanowiące połowę wszystkich nowotworów pierwotnych mózgu [3]. W przypadku glejaków radioterapia może obejmować jedynie lożę po usuniętym guzie, natomiast w leczeniu ognisk przerzutowych, muszą być spełnione odpowiednie kryteria między innymi liczba przerzutów mniejsza od trzech w przeciwnym wypadku napromienianiu zostaje poddany cały obszar mózgowia. W przypadku leczenia radykalnego dawka frakcyjna wynosi od 1,8 do 2 Gy do dawki całkowitej 50-6o Gy. Leczenie paliatywne to zazwyczaj od 5 do 10 frakcji. W przypadku napromieniania zmian przerzutowych w obszarze mózgowia stosuje się radiochirugię stereotaktyczną lub radioterapią stereotaktyczną. Leczenie stereotaktyczne realizuje się dla guzów o średnicy do $3 \mathrm{~cm}$, a dawka zadana wynosi w przypadku leczenia jednofrakcyjnego od 12 do 26 Gy lub od 6 do 8 Gy w przypadku trzech frakcji napromieniania. Przed przystąpieniem do procesu leczenia nowotworów mózgowia należy przeprowadzić szczegółową diagnostykę obrazową [4,5].

\section{Diagnostyka zmian w centralnym układzie nerwowym}

U pacjentów z podejrzeniem nowotworu centralnego układu nerwowego przeprowadza się szczegółowy wywiadlekarski. W przebiegu choroby nowotworowej o niskim stopniu złośliwościobjawy narastają stopniowo. Badania fizykalne i okulistyczne dostarczają informacji o odchyleniach neurologicznych charakterystycznych dla poszczególnych części mózgowia, a także o stanie narządu wzroku oraz dróg wzrokowych. Jednakże do postawienia prawidłowej diagnozy oraz podstawą procesu planowania leczenia w radioterapii nieodzowne są szczegółowe badania obrazowe. W pierwszej kolejności pacjent kierowany jest na badanie tomografem komputerowym (TK), więcej szczegółowych informacji dostarcza rezonans magnetyczny (MR) [2,3].

\section{Planowanie leczenia w radioterapii mózgowia}

W przypadku teleradioterapii obszaru mózgowia należy unieruchomić głowę pacjenta specjalną maską wykonaną z termoplastycznego tworzywa. Maska wymusza odpowiednią pozycję i ułatwia powtarzalne pozycjonowanie na stole terapeutycznym w trakcie całego kursu radioterapii. Podstawową metodą obrazowania jest tomografia komputerowa. Wynika to między innymi z faktu, iż dostępne systemy planowania leczenia (SPL) umożliwiają obliczenie oraz wizualizację rozkładu dawek wyłącznie na przekrojach tomografii komputerowej. Dla uzyskania dokładniejszych informacji o anatomii pacjenta w obszarze mózgowia niezbędnym jest wykonanie obrazowania za pomocą rezonansu magnetycznego [3,5].

Posiadając niezbędne badania obrazowe możliwe jest rozpoczęcie procesu planowania w SPL. Zanim to jednak nastąpi konieczne jest okonturowanie struktur anatomiczny pacjenta. System planowania leczenia interpretuje pojedynczy przekrój tomografii komputerowej jako zbiór pikseli, na tych przekrojach należy wyznaczyć kontury narządów krytycznych. Narządy krytyczne to struktury w ciele pacjenta posiadające 
określone wartości dawek tolerancji na promieniowania, których nie należy przekraczać w trakcie realizacji procedury napromieniania. W obszarze mózgowia są to oczy, nerwy wzrokowe, skrzyżowanie nerwów wzrokowych, pień mózgu [4,5]. Narządy krytyczne mogą być konturowane manualnie bądź automatycznie. Metoda manualna polega na obrysowaniu poszczególnych struktur kolejno na każdym przekroju tomografii komputerowej. Metoda automatyczna polega na wyznaczeniu konturów poszczególnych struktur dzięki narzędziom dostępnym w systemie planowania leczenia, mogą to być między innymi zaimplementowane atlasy anatomiczne $[6,7,8]$.

Celem pracy była ocena różnic w objętościach okonturowanych narządów krytycznych w obszarze mózgowiu wyznaczonych manualnie i automatycznie za pomocom narzędzi zaimplementowanych w trzech komercyjnych systemach planowania leczenia. Przeprowadzone badanie miało na celu zweryfikowanie czy dostępne w systemach planowania leczenia narzędzia służące do automatycznego wyznaczenia struktur krytycznych są porównywalne z manualnym sposobem konturowania. Precyzyjne wyznaczenie konturów narządów krytycznych jest jednym z ważniejszych etapów planowania leczenia w radioterapii. Wyznaczona w systemie planowania leczenia lokalizacja narządów krytycznych determinuje geometrię układu wiązek terapeutycznych oraz rozkład dawki promieniowania jonizującego w leczonym obszarze. Wszystkie te czynniki wpływają na skuteczność podjętego leczenia [9,10].

\section{Material}

Analizą zostały objęte badania tomografii komputerowej i rezonansu magnetycznego 33 pacjentów napromienianych $\mathrm{z}$ powodu nowotworu zlokalizowanego $\mathrm{w}$ obszarze mózgowia. Odległość pomiędzy warstwami przekrojów poprzecznych tomografii komputerowej wynosiła $2 \mathrm{~mm}$, a odległość pomiędzy warstwami rezonansu magnetycznego była równa $1 \mathrm{~mm}$. W systemie planowania leczenia Eclipse (Varian Medical Systems, Palo Alto, USA) za pomocą rejestracji/transformacji obrazów wykonywano fuzję obrazów tomografii komputerowej i rezonansu magnetycznego. Zastosowano transformację sztywną (ang. rigid), która prowadzi do połączenia obrazów poprzez skalowanie, przesunięcie i rotację obu obrazów. Proces transformacji sztywnej zilustrowano na rycinie 2 i 3 .

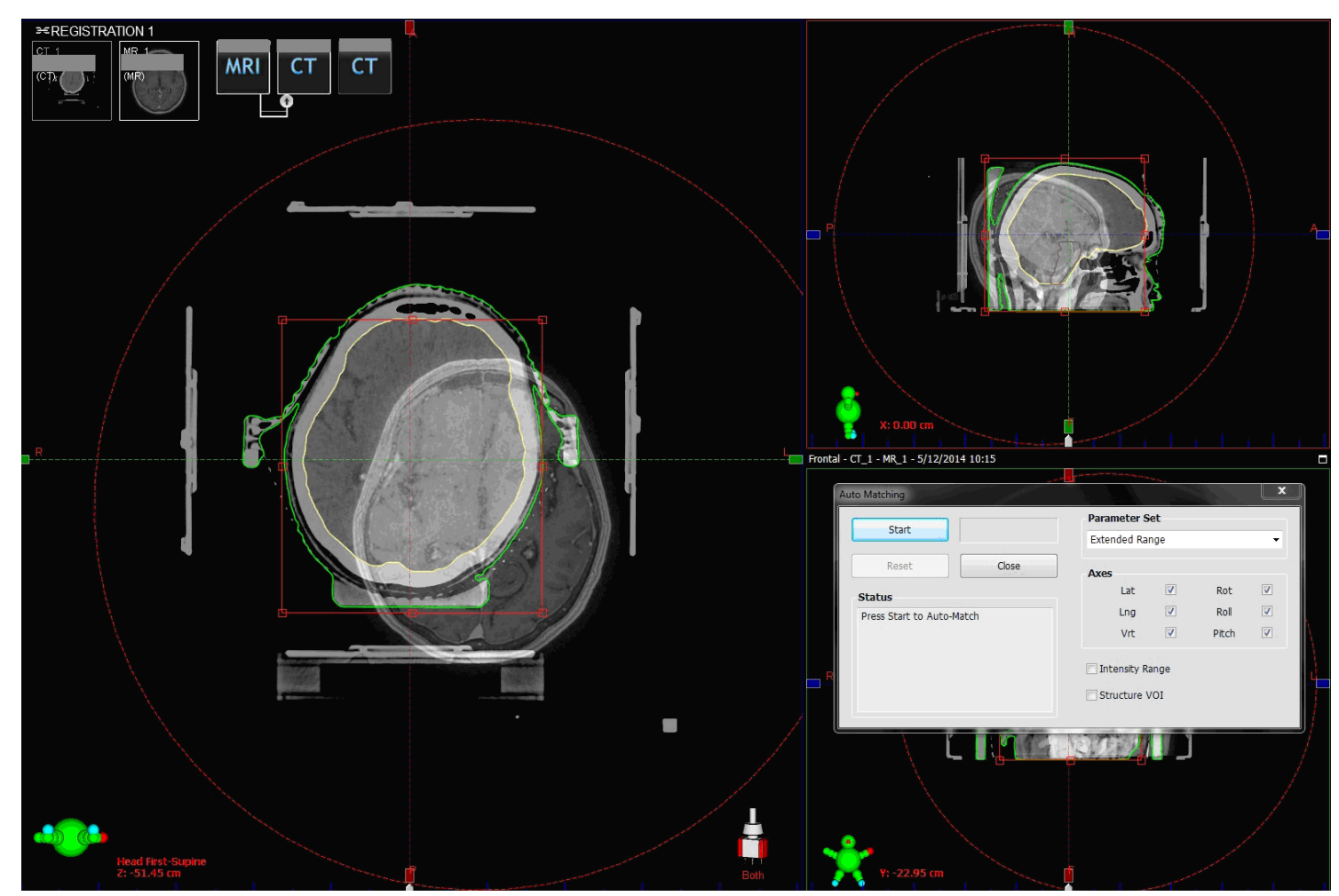

Rycina 2. Proces transformacji przekrojów tomografii komputerowej i rezonansu magnetycznego w systemie planowania leczenia Eclipse (Varian) dla przykładowego pacjenta z obszaru mózgowia. Źródło: mater 


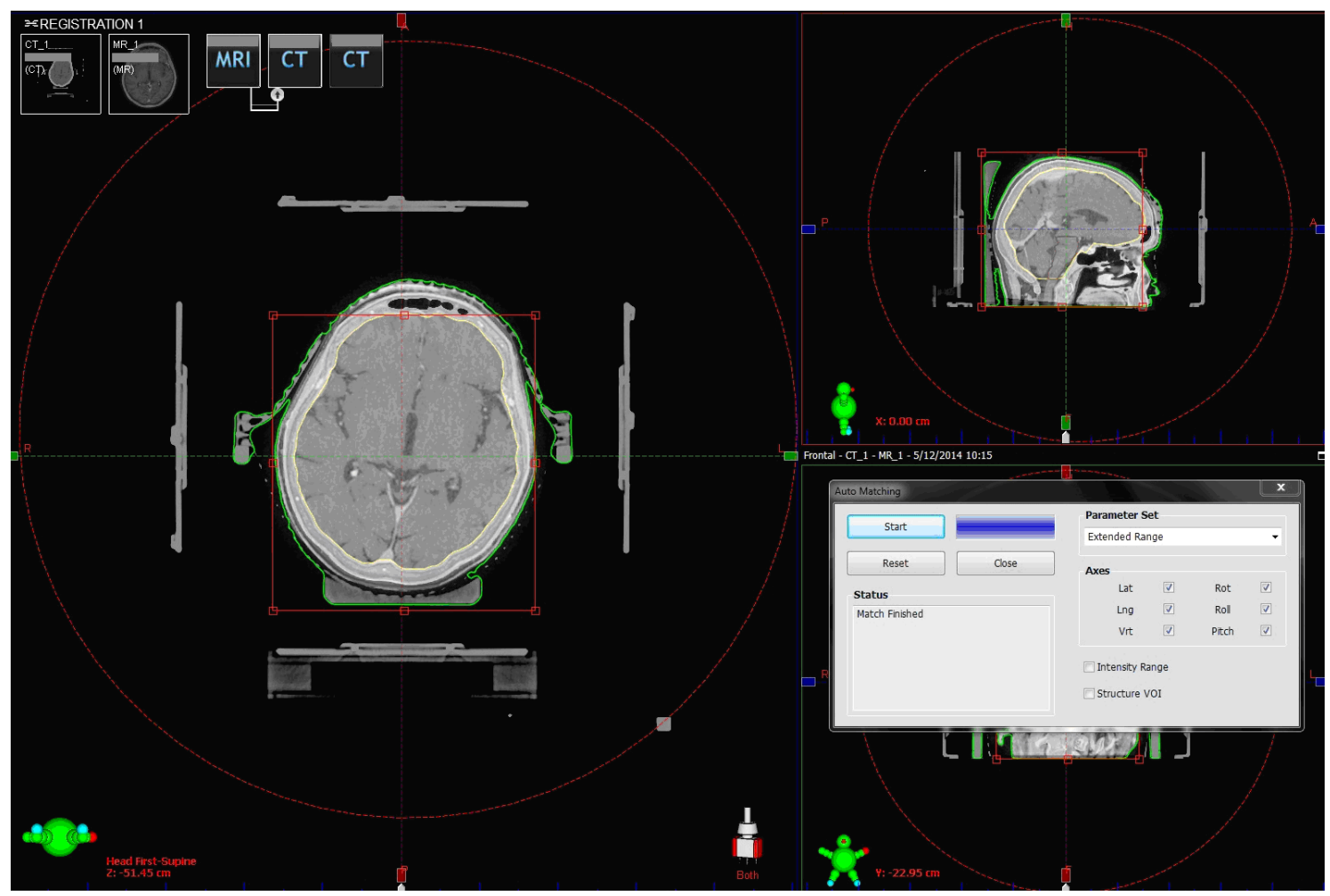

Rycina 3. Efekt fuzji przekrojów tomografii komputerowej i rezonansu magnetycznego w systemie planowania leczenia Eclipse (Varian) dla przykładowego pacjenta z obszaru mózgowia. Źródło: materiał własny.

Analizowane przekroje tomografii komputerowej i rezonansu magnetycznego zostały wyeksportowane do systemu planowania leczenia iPlan (BrainLab, Germany) - system planowania leczenia stereotaktycznego oraz MultiPlan (Accuray Incorporated, USA) - system planowania leczenia stereotaktycznego systemu CyberKnife. W obu systemach, tak jak w SPL Eclipse obrazy TK i MR zostały poddane fuzji obrazów. Proces transformacji obrazów TK i MR dla obszaru mózgowia w SPL MultiPlan zaprezentowano na rycinie 4.

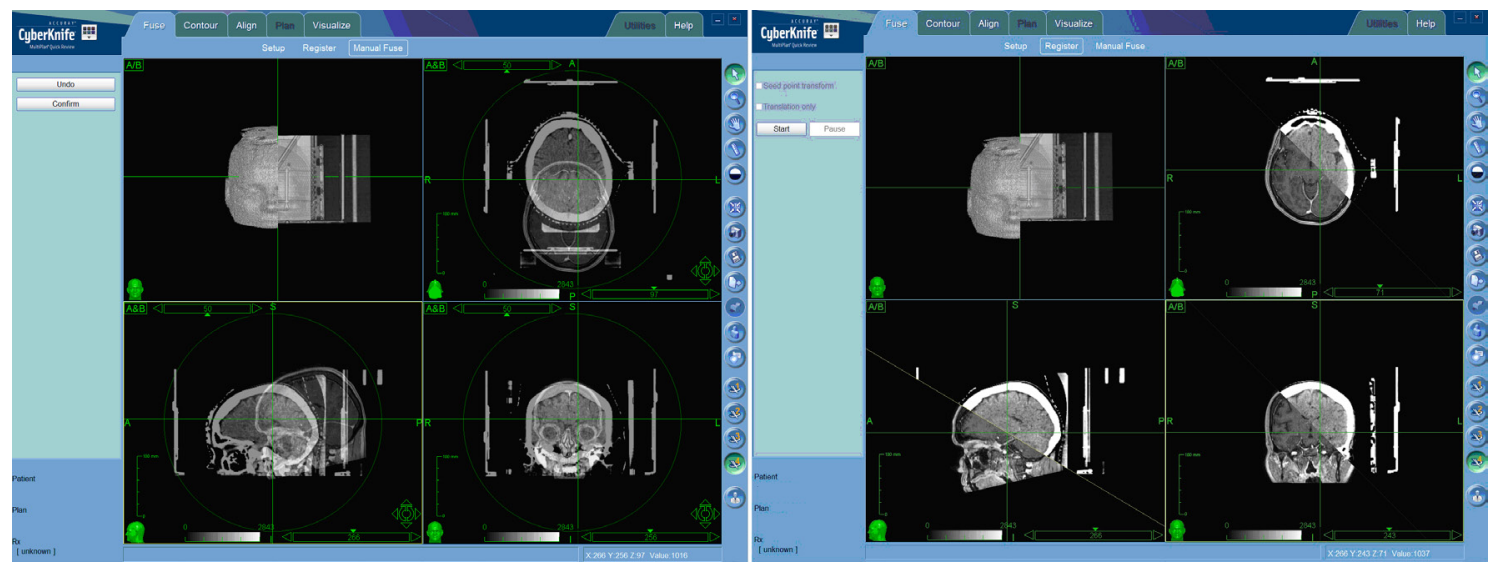

Rycina 4. Proces transformacji przekrojów tomografii komputerowej i rezonansu magnetycznego w systemie planowania leczenia Multiplan (Accuray) dla przykładowego pacjenta z obszaru mózgowia. Źródło: materiał własny.

\section{Metoda}

W trzech komercyjnych SPL: Eclipse, iPLan i MultiPlan na bazie fuzji obrazów przekrojów tomografii komputerowej i rezonansu magnetycznego, obrysowano manualnie kontury narządów krytycznych w obszarze mózgowia, a następnie wyznaczono ich objętości $\left[\mathrm{cm}^{3}\right]$. Następnie obrysowano kontury narządów 
krytycznych za pomocą automatycznych narzędzi zaimplementowanych w dwóch pozostałych systemach planowania leczenia. Dla każdego pacjenta okonturowano następujące narządy krytyczne:

Pień mózgu - struktura anatomiczna ośrodkowego układu nerwowego znajdująca się na podstawie czaszki, odpowiedzialna za utrzymanie najistotniejszych funkcji życiowych (oddychanie, praca serca, temperatura, itd.). Zgodnie z raportem ICRU 50 kontur pnia mózgu definiowano począwszy od podstawy czaszki do wysokości śródmózgowia [11].

Oko prawe, oko lewe - gałka oczna prawa; gałka oczna lewa. Kontur oka stanowiła wyraźnie widoczna gałka oczna w oczodole.

Soczewka oka prawego, soczewka oka lewego - część oka znajdująca się w przedniej części gałki ocznej między tęczówką, a ciałem szklistym. Kontur soczewki stanowił wyraźnie różniąca się gęstością (poziomem szarości w skali Hounsfield na obrazie TK) część oko w przedniej części okonturowano jako soczewkę.

Nerw wzrokowy prawy, nerw wzrokowy lewy - część drogi wzrokowej, przebiega od siatkówki do skrzyżowania wzrokowego. Kontur nerwu wzrokowego stanowił wyraźnie widoczny nerw odbiegający od oka ku tyłowi.

Skrzyżowanie nerwów wzrokowych - znajdujące się w śródmózgowiu miejsce skrzyżowania włókien nerwów wzrokowych. Kontur skrzyżowania nerwów wzrokowych stanowiło miejsce przecięcia nerwów wzrokowych.

Wizualizacja konturów narządów krytycznych obrysowanych manualnie w SPL Eclipse na przykładowym przekroju tomografii komputerowej na rycinie 6 a). Dzięki narzędziom dostępnym w SPL Eclipse możliwe było połączenie konturów na poszczególnych przekrojach TK lub MR, co pozwoliło na wyznaczenie całkowitego konturu analizowanych struktur, ich trójwymiarową wizualizację przedstawiono na rycinie 6 b), a następnie odczytano objętości analizowanych struktur.
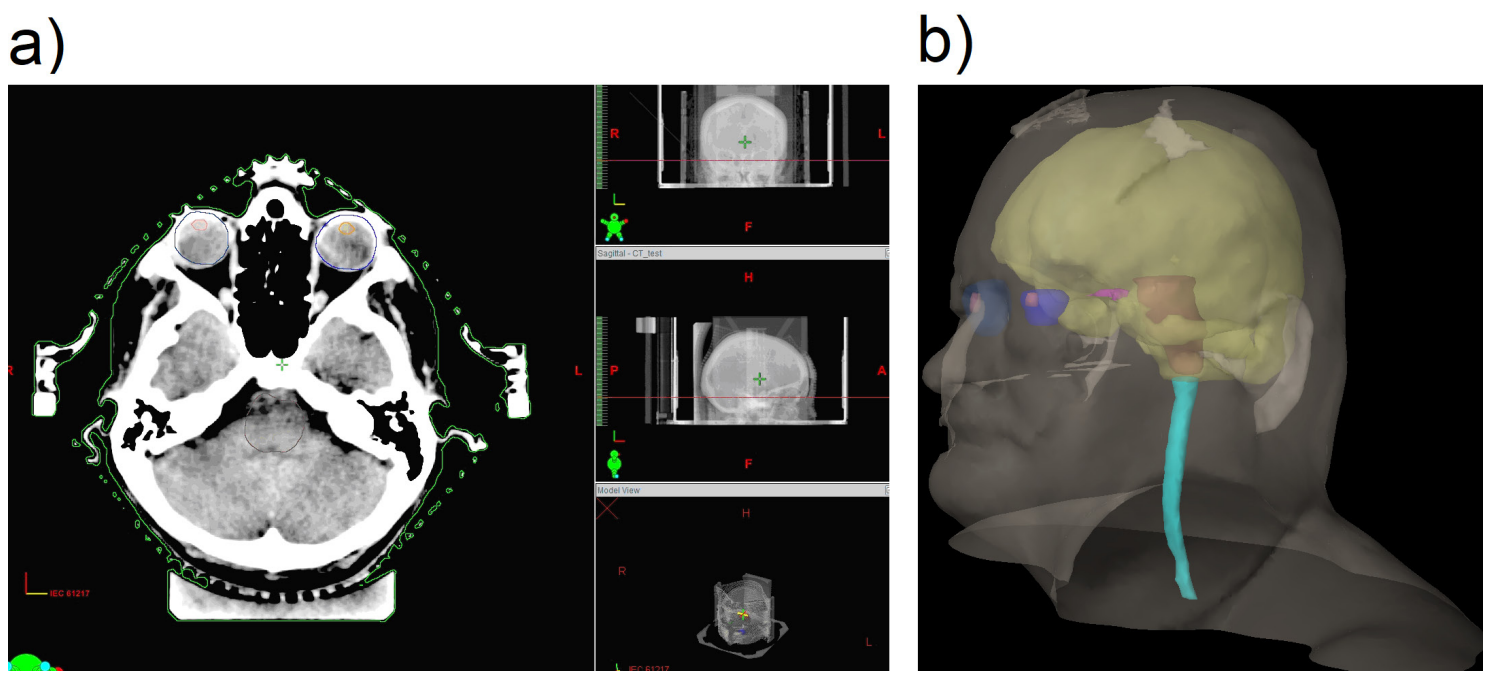

Rycina 5. Wizualizacja konturów narządów krytycznych w obszarze mózgowia w SPL Elipse: a) widok 2D na przykładowym przekroju tomografii komputerowej, b) trójwymiarowa wizualizacja. Źródło: materiał własny.

Następnie obrazy TK i MR analizowanej grupy pacjentów poddano fuzji obrazów kolejno w SPL iPlan i MultiPlan, w których okonturowano automatycznie badany zestaw narządów krytycznych obszaru mózgowia. W SPL iPlan do automatycznego konturowania wykorzystano zainstalowane atlasy anatomiczne dla obszaru mózgowia, korzystające z różnic w skali szarości poszczególnych struktur anatomicznych. W SPL MultiPlan również w procesie automatycznego konturowania wykorzystano zaimplementowane atlasy anatomiczne, których bazą są obrazy rezonansu magnetycznego.

Dla każdego pacjenta wyznaczono objętości analizowanych narządów krytycznych trzema metodami w trzech SPL: metodą manualną w SPL Eclispe, automatyczną w SPL iPlan, automatyczną w SPL MultiPlan. 


\section{Wyniki}

\section{- Objętości narządów krytycznych dla reprezentatywnego pacjenta}

Na wykresie 1 i 2 przedstawiono różnice w objętościach poszczególnych narządów krytycznych wyznaczonych dwoma metodami w trzech analizowanych SPL: Eclipse, iPlan oraz MultiPlan. Ze względu na duże różnice w wartościach objętości analizowanych struktur podzielono narządy na dwie grupy, na wykresie 1 przedstawiono narządy o objętościach powyżej kilku $\mathrm{cm}^{3}$, na wykresie 2 zaprezentowano narządy o objętościach nie przekraczających $1 \mathrm{~cm}^{3}$.

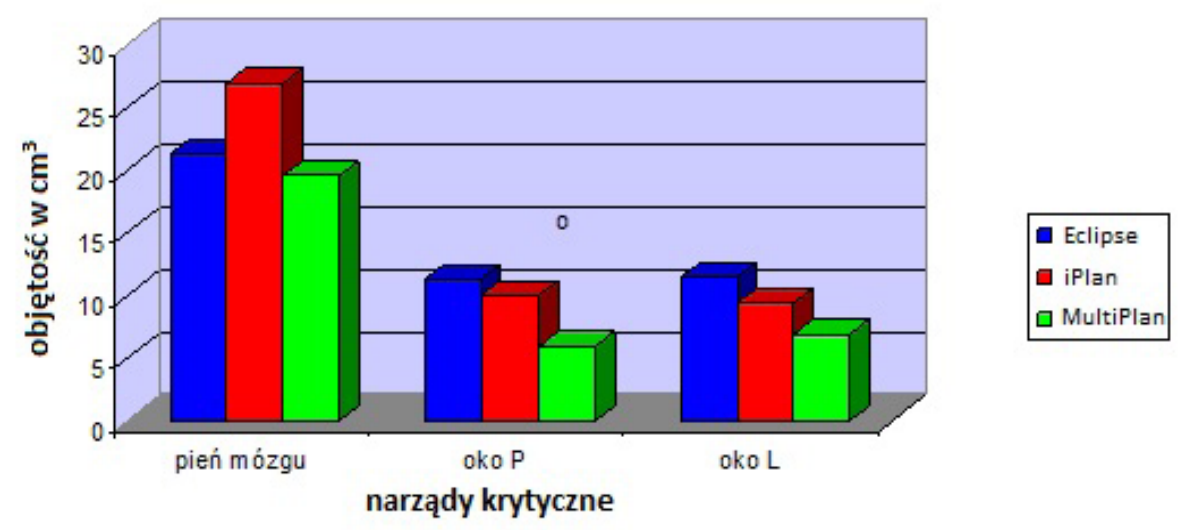

Wykres 1. Porównanie objętości dużych narządów krytycznych obszaru mózgowia (o objętości powyżej 1cm³) dla reprezentatywnego pacjenta w systemach planowania leczenia Eclipse, iPlan oraz MultiPlan. Źródło: materiał własny.

Na wykresie 1 można zaobserwować widoczne różnice w objętościach narządów krytycznych w trzech analizowanych SPL. Widoczna jest tendencja wyznaczania największych objętości w sposób manualny, najmniejsze objętości wyznaczono w SPL MultiPlan w porównaniu do pozostałych SPL.

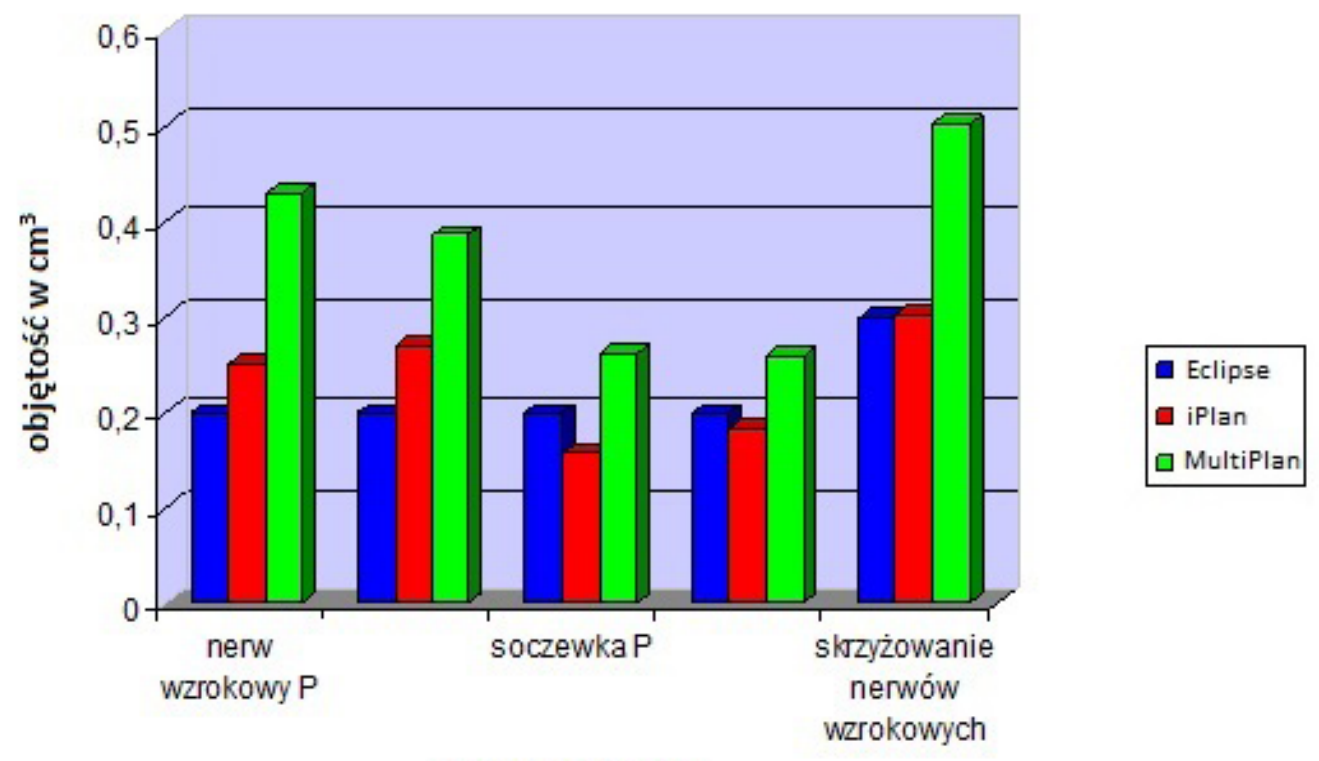

narządy krytyczne

Wykres 2. Porównanie objętości małych narządów krytycznych obszaru mózgowia (o objętości poniżej 1cm³) dla reprezentatywnego pacjenta w systemach planowania leczenia Eclipse, iPlan oraz MultiPlan. Źródło: materiał własny. 
W przypadku struktur o większych mniejszych niż $1 \mathrm{~cm}^{3}$ widocznych na wykresie 2 konturując manualnie w SPL Eclipse wygenerowano najmniejsze objętości w stosunku do automatycznych narzędzi wykorzystanych w SPL iPlan i MultiPlan. Narzędzia w SPL iPlan pozwoliły na wyznaczenie znacząco większych objętości dla nerwów wzrokowych, soczewek i skrzyżowania nerwów wzrokowych. Objętości poszczególnych nerwów wzrokowych, skrzyżowania nerwów wzrokowych oraz soczewek wyznaczane automatycznie w SPL iPlan i manualnie w SPL Eclipse były bardzo zbliżone.

\section{- Objętości narządów krytycznych dla całej analizowanej grupy pacjentów}

Dla zebranych parametrów, tj. dla wszystkich analizowanych objętości narządów krytycznych w SPL Eclipse, iPlan i MultiPlan, przeprowadzono analizę statystyczną obejmującą wartości średnie objętości wraz z odchyleniem standardowym i wyznaczono 95\% przedziały ufności. Wyniki pogrupowano interpretując kolejno objętości narządów krytycznych w poszczególnych systemach planowania leczenia.

Pierwszym z analizowanych narządów z obszaru mózgowia był pień mózgu. Manualne konturowanie pnia mózgu, ze względu na jego rozmiar było procesem czasochłonnym. Narząd ten jest stosunkowo duży, widoczny na większości przekrojów obszaru mózgowia. Na wykresie 3 przedstawiono wyniki objętości pnia mózgu w zależności od SPL i rodzaju narzędzia służącego do wyznaczenia konturu analizowanej struktury krytycznej.

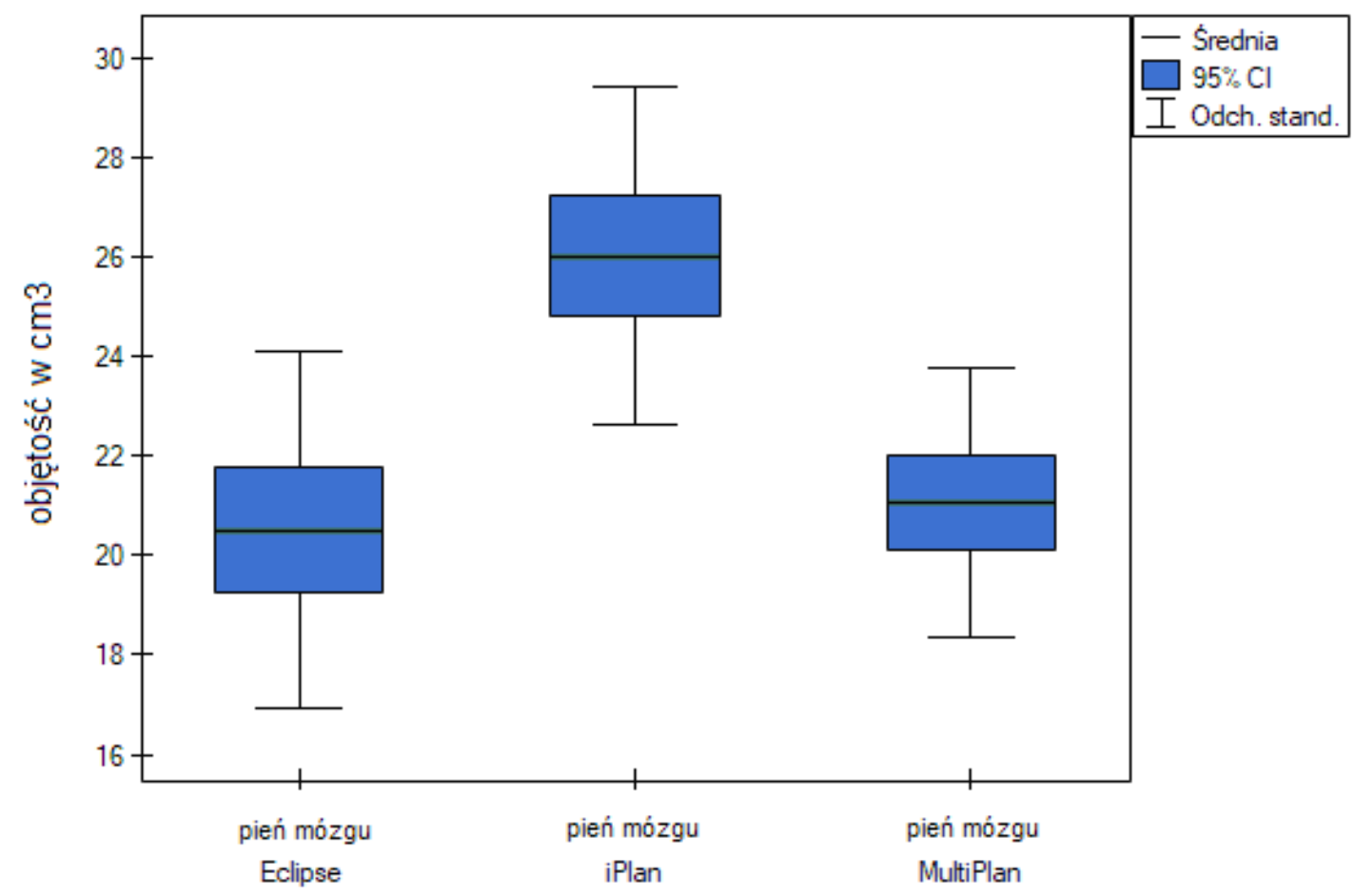

Wykres 3. Wykres przedstawiający objętości pnia mózgu wyznaczone w trzech systemach planowania leczenia Eclipse, iPlan i MultiPlan dla wszystkich 33 pacjentów. Pionowe słupki oznaczają 95\% przedział ufności. Źródło: materiał własny.

Jak wynika z przedstawionych danych, objętości pnia mózgu wyznaczone w systemie planowania leczenia MultiPlan oraz wyznaczone ręcznie w systemie Eclipse są bardzo zbliżone nie stwierdzono statystycznie istotnej różnicy między nimi. System planowania leczenia iPlan wyznaczał objętość pnia mózgu średnio o 25\% większą w porównaniu do dwóch pozostałych analizowanych sposobów wyznaczenia danych obszarów.

Kolejnym analizowanym narządem było oko prawe. Na wykresie 4 przedstawiono dane, z których wyraźnie wynika, że objętości wyznaczone manualnie w SPL Eclipse oraz te wyznaczone automatycznie w SPL iPlan są do siebie bardzo zbliżone. Objętości wyznaczone przez narzędzia dostępne w systemie planowania leczenia MultiPlan są wyraźnie większe. 


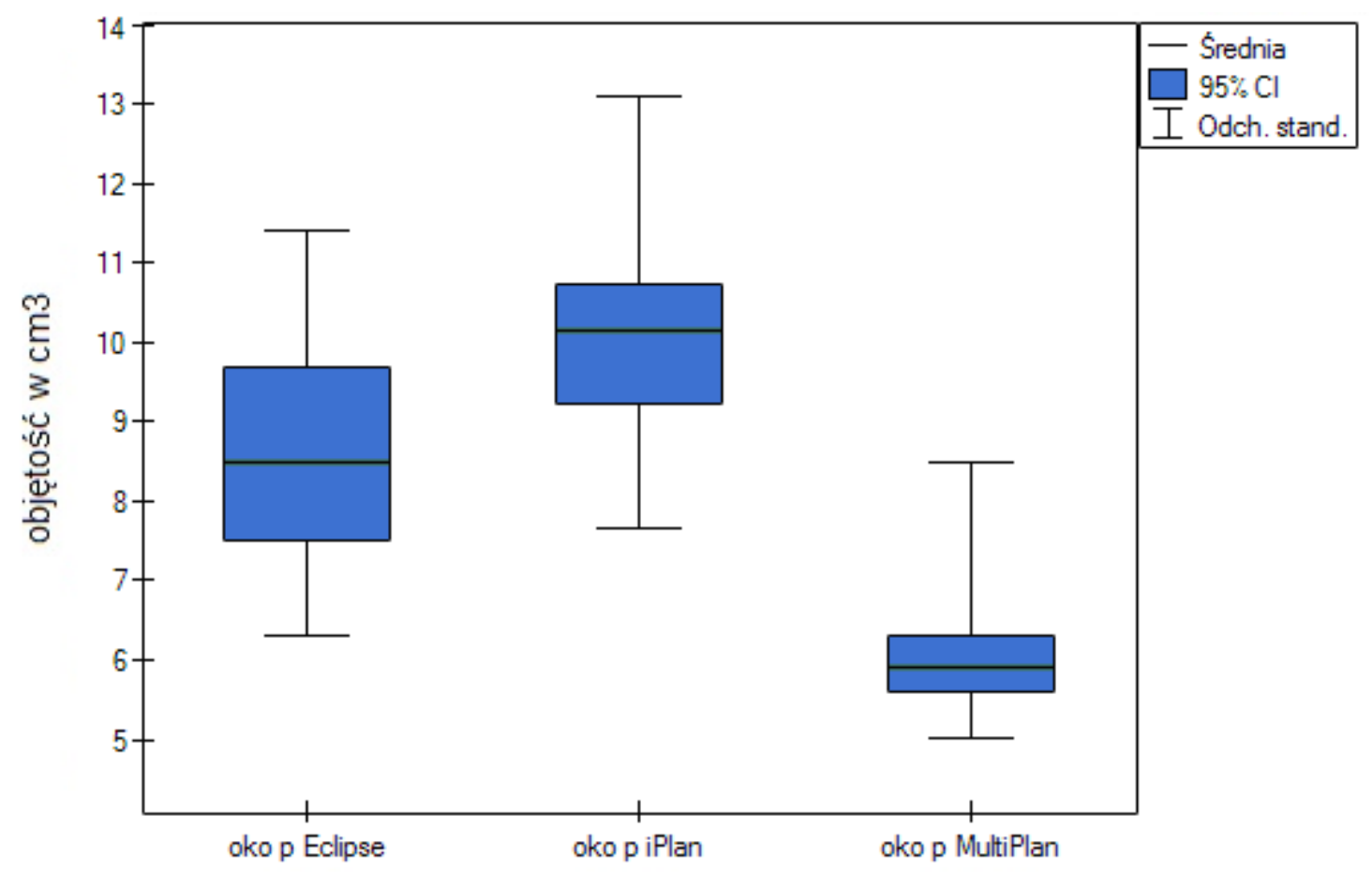

Wykres 4. Wykres przedstawiający objętości oka prawego wyznaczone w trzech systemach planowania leczenia Eclipse, iPlan i MultiPlan dla wszystkich 33 pacjentów. Źródło: materiał własny.

Podobne wyniki otrzymano dla oka lewego. W tym przypadku objętości w SPL iPlan były zauważalnie większe od tych otrzymanych w systemach planowania leczenia Eclipse i Multiplan. Wyniki zilustrowano na wykresie 5 .

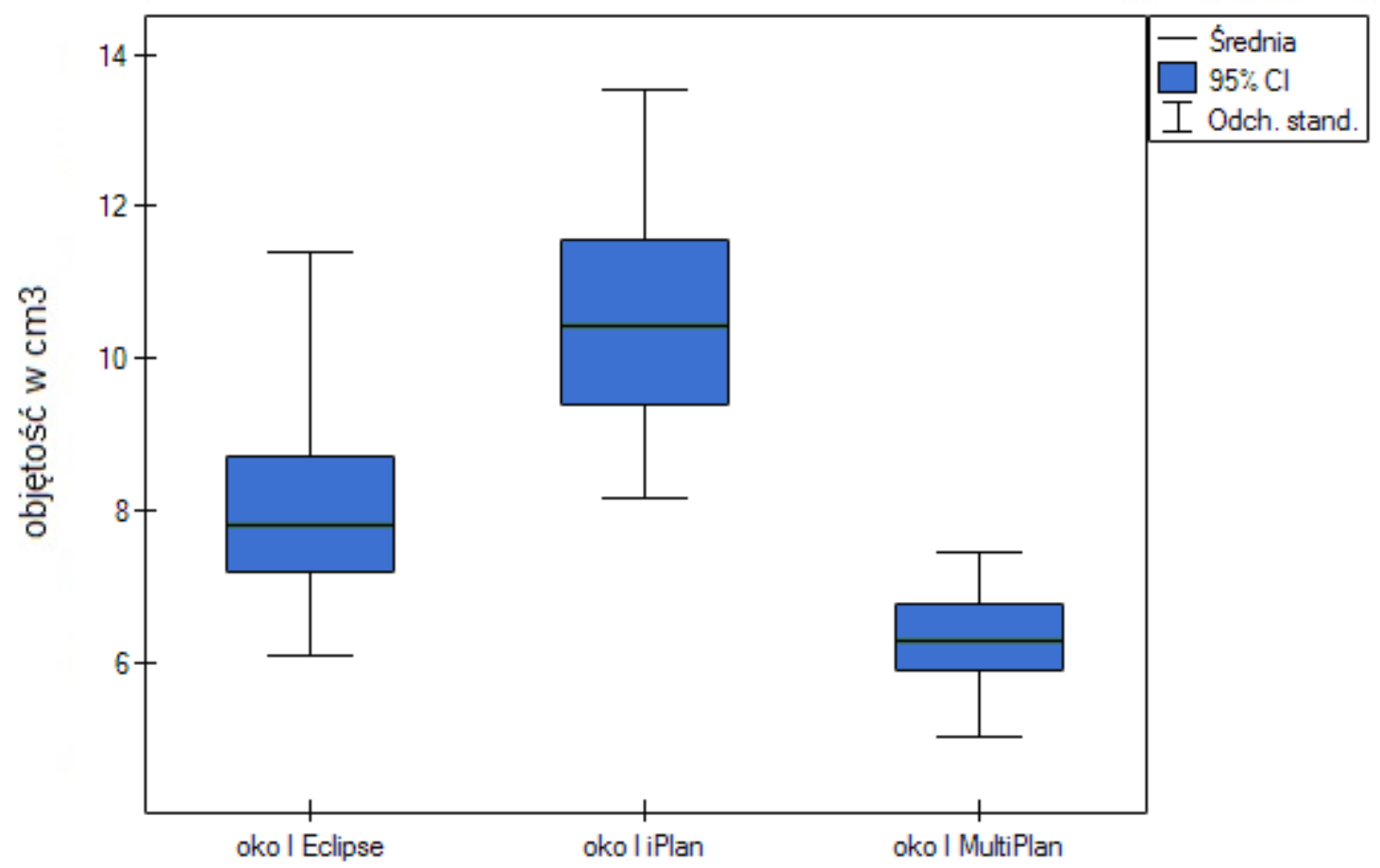

Wykres 5. Wykres przedstawiający objętości oka lewego wyznaczone w trzech systemach planowania leczenia Eclipse, iPlan i MultiPlan dla wszystkich 33 pacjentów. Źródło: materiał własny. 
Kolejnym krokiem było przystąpienie do analizy wyników objętości struktur, dla których zaobserwowano większe różnice $\mathrm{w}$ objętościach $\mathrm{w}$ SPL MultiPlan. Jednakże dla tak małych narządów różnice te nie są znaczące. Na wykresach 6 i 7 przedstawiono otrzymane objętości nerwów wzrokowych oraz soczewek w trzech analizowanych systemach planowania leczenia: Eclipse, iPlan i MultiPlan (wyniki dla nerwu wzrokowego lewego i prawego oraz soczewki lewej i prawej były bardzo zbliżone, dlatego zostały uśrednione i przedstawione na jednym wykresie).

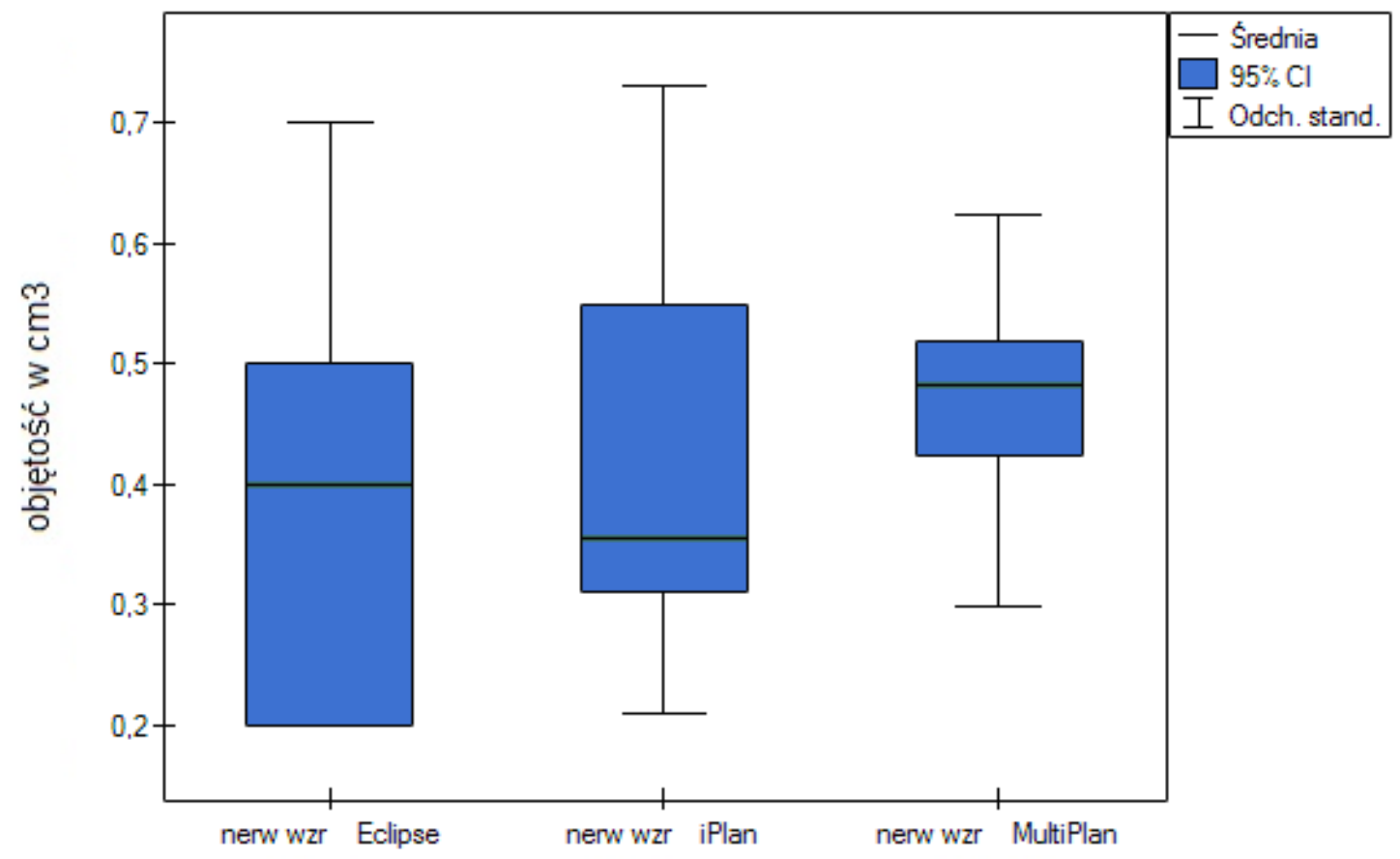

Wykres 6. Wykres przedstawiający objętości [cm3] nerwów wzrokowych wyznaczone w trzech systemach planowania leczenia Eclipse, iPlan i MultiPlan dla wszystkich 33 pacjentów. Źródło: materiał własny.

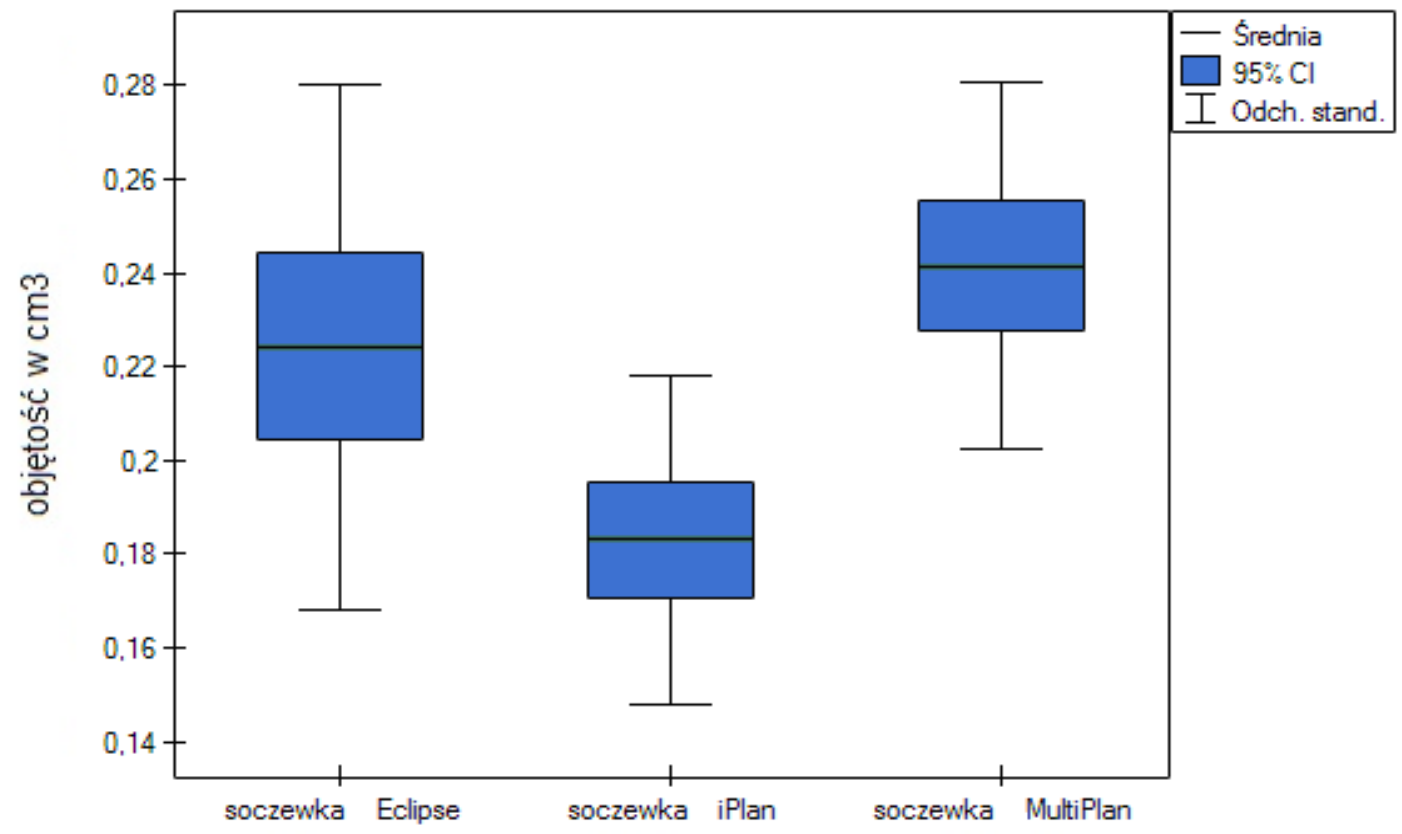

Wykres 7. Wykres przedstawiający objętości [cm3] soczewek wyznaczone w trzech systemach planowania leczenia Eclipse, iPlan i MultiPlan dla wszystkich 33 pacjentów. Źródło: materiał własny. 


\section{Analiza powtarzalności wyników objętości narządów krytycznych}

Dla losowo wybranych trzech pacjentów w kilkutygodniowych odstępach systemie planowania leczenia Eclipse w oparciu o te same przekroje tomografii komputerowej i rezonansu magnetycznego powtórzono proces manualnego wyznaczenia czterech narządów krytycznych: pnia mózgu, oka, soczewki i nerwu wzrokowego prawego. Poszczególne wyniki wraz z obliczoną wartością średnią i odchyleniem standardowym dla poszczególnych struktur przedstawiono w tabeli 1.

Tabela 1. Wyniki trzykrotnego wyznaczania objętości pnia mózgu, oka, soczewki i nerwu wzrokowego prawego wraz z wartościami średnimi i odchyleniem standardowym dla jednego z pacjentów, wyznaczane w systemie Eclipse przez tego samego operatora.

\begin{tabular}{|c|c|c|c|c|}
\hline l.p. & pień mózgu [cm³] & oko prawe $\left[\mathrm{cm}^{3}\right]$ & $\begin{array}{c}\text { soczewka prawa } \\
{\left[\mathrm{cm}^{3}\right]}\end{array}$ & $\begin{array}{c}\text { nerw wzrokowy } \\
\text { prawy }\left[\mathrm{cm}^{3}\right]\end{array}$ \\
\hline 1 & 23,3 & 7,7 & 0,2 & 0,4 \\
\hline 2 & 23,8 & 7,4 & 0,2 & 0,4 \\
\hline 3 & 21,9 & 7,5 & 0,2 & 0,5 \\
\hline średnia & 23,00 & 7,53 & 0,2 & 0,43 \\
\hline $\mathrm{SD}$ & 0,98 & 0,15 & $\mathrm{O}$ & 0,06 \\
\hline
\end{tabular}

Z analizy wyników z tabeli 1 ten sam operator konturując kilkukrotnie te same struktury, za każdym razem może otrzymać różną objętość konturu, przy czym otrzymywane wyniki są bardzo zbliżone, co ukazuje obliczona wartość średnia i niskie wartości odchylenia standardowego. Nieznaczne różnice są nie do uniknięcia i nie powinny wpływać na proces leczenia.

\section{Dyskusja}

Zgromadzone wyniki wykazują niewielkie rozbieżności w objętościach narządów krytycznych wyznaczonych manualnie w systemie planowania leczenia Eclipse i przy użyciu narzędzi automatycznego konturowania dostępne w SPL iPlan oraz MultiPlan. Różnice te są nieznaczne i nie mogą mieć wpływu na proces przygotowania planu i skuteczność leczenia.

Jak już zaznaczono wcześniej każdy wynik pomiaru jest jedynie przybliżeniem faktycznej wielkości mierzonej. Pomiar jest zawsze niedokładny. Wynika to z niedoskonałości dostępnej aparatury, samej metody pomiaru, a także zmysłu wzroku operatora. Błąd jest nieodłączną cechą pomiaru.

Na podstawie przeprowadzonych badań i analizy otrzymanych wyników w pracy wykazano, że zbadane narzędzia do automatycznego konturowania narządów krytycznych charakteryzują się błędem wynikający z ograniczonych zasobów zaimplementowanych atlasów anatomicznych. Uzyskane kontury struktur są uśrednieniem anatomii pewnej grupy pacjentów i nie przewidują indywidualnych odchyleń. Manualne metody wyznaczania struktur krytycznych również obarczone są pewnym błędem, powodem tego jest niedoskonałość narzędzia jakim jest wzrok ludzki. Wyznaczając kilkukrotnie objętości struktur krytycznych dla tego samego pacjenta, w oparciu o te same badania tomografii komputerowej i rezonansu magnetycznego, przygotowane przez tą samą osobę wykazano, że wyniki różnią się między sobą nieznacznie, nie ma to wpływu na sam proces konturowania.

W pracy autorstwa Yamazaki H. i współautorów opublikowanej w Radiot. Oncol. w 2011 r. przedstawiono wyniki badania w oparciu o 21 planów radioterapii w systemie CyberKnife [12]. Plany zostały przygotowane przez 11 klinicystów w 7 różnych ośrodkach, przeanalizowano różnice w objętościach i konturach narządów krytycznych oraz objętości planowanej do napromieniania PTV (ang. Planning Target Volume). Na rycinie 14 przedstawiono nałożone na siebie kontury analizowanych w pracy struktur okonturowanych przez kilku operatorów dla jednego z pacjentów [12]. 

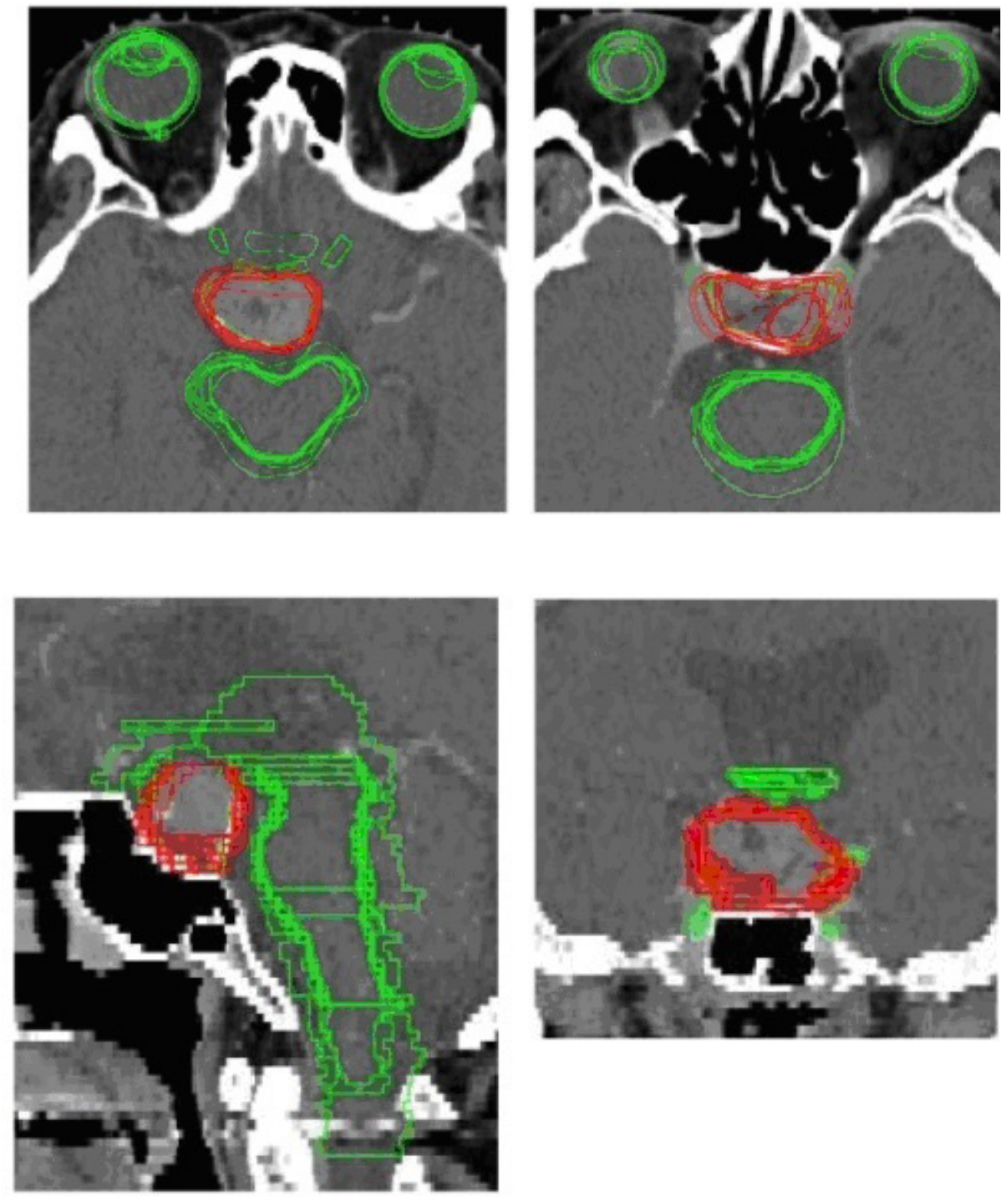

Rycina 7. Wynik nałożenia konturów narządów krytycznych oraz objętości PTV wyznaczonych przez 7 operatorów dla tego samego pacjenta. Źródło: Yamazaki H, Shiomi H, Tsubokura T, et al. Quantitative assessment of interobserver variability in target volume delineation on stereotactic radiotherapy treatment for pituitary adenoma and meningioma near optic tract. Radiat Oncol. 2011 Jan 27;6:10 [12].

W pracy wykazano, że różnice w objętościach i konturach narządów krytycznych oraz PTV sięgające kilkunastu procent. Jednak dzięki kontroli jakości polegającej na weryfikacji obrysów przez drugą osobę grube błędy zostały wykryte i poprawione, a pozostałe drobne różnice w objętościach struktur nie mają znaczącego wpływu na proces planowania leczenia [12].

Analiza zebranych danych pozwala na stwierdzenie, iż z wykorzystaniem dostępnych badań obrazowych takich jak tomografia komputerowa i rezonans magnetyczny w systemach planowania leczenia szacujemy granice narządów z pewnym błędem. Dostępne narzędzia pozwalają na dość dokładne i powtarzalne wyniki.

Każde z dostępnych narzędzi służących do wyznaczania objętości narządów krytycznych są obarczone błędem. Biorąc pod uwagę błąd ludzki, wynikający z niedokładności narzędzia jakim jest wzrok oraz niedoskonałość narzędzi pomiarowych, można stwierdzić, że każda metoda pomiaru jest obarczona pewnym błędem. Porównanie wielkości obu błędów wykazało, że są zbliżone. W pracy wykazano, że metody automatyczne można z powodzeniem stosować w przygotowywaniu planów leczenia. Nie ma możliwości na 
idealne odwzorowanie konturów struktur ludzkiego organizmu. Każdy z operatorów wyznacza je w nieco inny sposób. Ponadto ten sam operator nie jest w stanie w identyczny sposób wielokrotnie odwzorować wyznaczonego przez siebie kontury. Manualne wyznaczanie pewnych struktur na przekrojach z tomografii komputerowej wykonywanej z odległością pomiędzy warstwami wynoszącą $2 \mathrm{~mm}$ oraz porównanie ich z dostępnym badaniem rezonansu magnetycznego zajmuje nierzadko wiele godzin. Narzędzia służące do automatycznego konturowania pozwalają na skrócenie czasu przygotowania konturów, a tym samym skróceniu ulega całkowity czas przygotowania planu leczenia. Oznacza to zysk dla pacjenta wynikający ze skrócenia czasu oczekiwania pacjenta na przystąpienie do procesu terapii.

\section{Wnioski}

Należy pamiętać, że nawet niewielki błąd może w krytyczny sposób wpłynąć na proces leczenia pacjenta. Trzeba zachować szczególną ostrożność przy wyznaczaniu narządów krytycznych. Niezmiernie istotne jest przestrzeganie i ciągłe podnoszenie standardów w tym zakresie. Na każdym etapie przygotowania leczenia, niezależnie od zastosowanej metody automatyzacji, powinna następować weryfikacja jej wyników przez człowieka. Można zatem stwierdzić, że korzystając z funkcji automatycznego wyznaczania struktur krytycznych godzimy się na pewne przeszacowania lub niedoszacowania, ale przeważają korzyści związane ze znacznym skróceniem czasu przygotowania planu leczenia.

Objętości struktur wyznaczonych manualnie w SPL Eclipse są większe od otrzymanych przy użyciu narzędzi zaimplementowanych w systemach planowania leczenia iPlan i MultiPlan. Różnice te są najistotniejsze w narządach krytycznych, których objętość nie przekracza $1 \mathrm{~cm}^{3}$, czyli soczewki oraz nerwy wzrokowe. Różnice w objętościach narządów krytycznych wyznaczone w trzech systemach planowania leczenia Eclipse, iPlan i MultiPlan nie wpływają na bezpieczeństwo pacjenta w procesie leczenia.

\section{Konflikt interesu/Conflict of interest}

Nie występuje. / None.

\section{Etyka/Ethics}

Treści przedstawione w artykule są zgodne z zasadami Deklaracji Helsińskiej, dyrektywami EU oraz ujednoliconymi wymaganiami dla czasopism biomedycznych. / The content presented in the article is consistent with the principles of the Helsinki Declaration, EU directives and unified requirements for biomedical magazines.

\section{Bibliografia}

[1] Krajowy rejestr nowotworów. http://onkologia.org.pl.

[2] Kordek R. Onkologia. Podręcznik dla studentów i lekarzy. Wyd. trzecie, poprawione, Via Medica: Gdańsk 2007.

[3] http://www.doctormed.pl/wydzial/300/artykul/427/Nowotwory\%20centralnego\%20 uk\%C5\%82adu\%2onerwowego.

[4] Crevoisier R, Pierga JY, Dendale R, et al. Radiotherapy of glioblastoma, Cancer Radiother 1997;1:194207.

[5] Wen PY, Weller M, Quant Lee E, et al. Glioblastoma in adults: a Society for Neuro-Oncology (SNO) and European Society of Neuro-Oncology (EANO) consensus review on current management and future directions. Neuro Oncol. 2020 Aug 17;22:1073-113.

[6] Kruser TJ, Bosch WR, Badiyan SN, et al. NRG brain tumor specialists consensus guidelines for glioblastoma contouring. J Neurooncol. 2019;143:157-66.

[7] Shah JL, Li G, Shaffer JL, et al. Stereotactic Radiosurgery and Hypofractionated Radiotherapy for Glioblastoma. Neurosurgery. 2018;82:24-34.

[8] Barani IJ, Larson DA. Radiation therapy of glioblastoma. Cancer Treat Res. 2015;163:49-73. 
[9] Lillie O’Steen, Robert J Amdur. An approach to contouring the dorsal vagal complex for radiotherapy planning. Med Dosim . Spring 2016;41:7-8.

[10] Niyazi M, Brada M, Chalmers AJ, et al. ESTRO-ACROP guideline "target delineation of glioblastomas". Radiother Oncol. 2016;118:35-42.

[11] ICRU Report 50. Prescribing, Recording and Reporting Photon Beam Therapy. International Commission on Radiation Units and Measurements 1993.

[12] Yamazaki H, Shiomi H, Tsubokura T, et al. Quantitative assessment of inter-observer variability in target volume delineation on stereotactic radiotherapy treatment for pituitary adenoma and meningioma near optic tract. Radiat Oncol . 2011;610. 